\title{
Pemberdayaan Masyarakat dalam Bentuk Pengolahan Daging Rajungan Menjadi Nugget Sehat
}

\author{
Dewiantika Azizah $^{1}$, Mutiara Dwi Cahyani ${ }^{2}$, Nurwanti Fatnah ${ }^{3}$ \\ 1,2Departement of Chemistry Education Muhammadiyah University of Cirebon \\ ${ }^{3}$ Departement of Sains Education Muhammadiyah University of Cirebon \\ Email: antika.unique@gmail.com
}

\begin{abstract}
Abstrak
Masyarakat desa mertasinga umumnya bekerja sebagai pengumpul daging rajungan, yang kemudian hasilnya dijual ke pabrik - pabrik, jika masyarakat mempunyai keahlian mengolah daging rajungan tersebut menjadi aneka makanan tentunya akan memberikan nilai ekonomis yang lebih tinggi, jika dibandingkan hanya mengumpulkan daging saja. Tujuan pengabdian masyarakat adalah memberdayakan masyarakat untuk mengolah daging rajungan menjadi nugget rajungan, agar dapat menghasilkan nilai jual yang lebih tinggi jika dibandingkan hanya menjual daging rajungan saja sehingga dapat meningkatkan pendapatan warga. Teknik sampling yang digunakan adalah simple random sampling. Dengan menggunakan teknik pengumpulan data dilakukan melalui pengamatan, wawancara dan dokumentasi. Data dianalisis dengan menggunakan teknik analisis data deskriptif kualitatif. Hasil pengabdian ini adalah keterampilan peserta dalam membuat nugget rajungan yang sehat dan bergizi tinggi tanpa zat adiptif sintetis didapatkan nilai rata - rata peserta sebesar $82,075 \%$. Kesimpulan dari pengabdian ini adalah pengolahan daging rajungan agar mempunyai nilai jual yang lebih tinggi dapat diolah menjadi nugget, dengan menjaga kualitas rasa dan gizi agar enak dan aman dikonsumsi maka digunakanlah zat adiptif dari bahan alami.
\end{abstract}

Kata Kunci: keterampilan, nuget rajungan, makanan

\begin{abstract}
Mertasinga people generally work as collectors of crab's meat, then it is sold to factories, if people have skill to process crab meat into various foods, it will provide a higher economic value, if compared to just gathering meat alone. The purpose of community service is to empower Mertasinga people to process crabs' meat become crabs' nugget, so that it can produce a higher selling value rather than just selling crabs' meat and it can increase peoples' income. The sampling technique used simple random sampling. Technique of data collection is done by observation, interviews and documentation. Data were analyzed using qualitative descriptive data analysis techniques. The result of this study is the participant's skill in making healthy and highly nutritious crabs' nuggets without synthetic additive substances obtained an average participant value of $82.075 \%$. The conclusion of this study is the processing of small crabs' meat to achieve a higher selling value can be processed into nuggets, by maintaining the quality of taste and nutrition, so that it is delicious and safe to consume and use an addictive substance from natural ingredients.
\end{abstract}

Keywords: Enhancement peoples' skills, crab nugget production, healthy food 


\section{PENDAHULUAN}

Desa Mertasinga terletak di kecamatan Gunungjati kabupaten Cirebon. Berdasarkan hasil wawancara dengan perangkat desa didapatkan data bahwa Desa Mertasinga memiliki jumlah penduduk sebanyak 6.621 orang, dengan jumlah laki - laki sebanyak 3.563 orang dan perempuan sebanyak 3.058 orang. Sebagian besar warga desa beragama Islam.

Desa Mertasinga memiliki luas wilayah 93 Hektar, sedangkan untuk batas wilayahnya akan diuraikan sebagai berikut :
a. Sebelah Utara
: Wilayah Desa Sirnabaya dan Desa Purwawinangun
b. Sebelah Timur
: Laut Jawa
c. Sebelah Barat
: Wilayah Desa Sinarbaya
d. Sebelah Selatan
: Sungai Bondet

Batas wilayah tersebut menggambarkan bahwa desa Mertasinga merupakan daerah pesisir dengan potensi unggulan, yang selalu ditangkap oleh warga adalah rajungan (Profil Desa Mertasinga, 2018). Rajungan yang sudah diambil dikuliti dan diambil dagingnya oleh warga untuk dipasarkan baik di dalam maupun luar negeri. Untuk kualitas ekspor daging rajungan yang dikirim adalah daging rajungan pasteurisasi yang digolongkan dalam daging kualitas satu. Sedangkan untuk pemasaran dalam negeri yang digunakan adalah daging kualitas ke-2 yakni daging yang masuk kelompok sterilisasi (Ubaidillah, dkk, 2010).

Mereka belum mempunyai pengetahun untuk mengolah daging rajungan tersebut agar mempunyai nilai ekonomis yang lebih tinggi jika dibandingkan dengan hanya menjual dagingnya saja. Berakar dari masalah tersebut, maka sebagai bentuk pengabdian masyarakat, kami berupaya memberikan pengetahuan mengenai pengolahan daging rajungan menjadi nuget. Nugget merupakan produk olahan daging, ditutupi oleh perekat tepung, kemudian dilumuri dengan tepung panir dan dilakukan proses penggorengan setengah masak, setelah itu dibekukan agar mutunya tetap terjaga pada saat proses penyimpanan (Wulandari, dkk, 2016).

Proses pembuatan nugget adalah melalui proses pengukusan daging nugget yang telah dibumbui. Proses pengukusan dapat mengurangi jumlah protein yang terkandung dalam rajungan. Pengukusan menyebabkan air banyak yang keluar dari daging sehingga terjadi proses koagulasi yang membuat tekstur menjadi padat dan terbentuklah struktur protein yang lebih sederhana, karena mengalami denaturasi (Jacoeb dkk, 2012). Denaturasi merupakan perubahan struktur molekul tanpa memutuskan ikatan peptida pada struktur protein (Diniz, dkk, 2013. Pada proses ini nilai protein tidak akan berkurang namun bisa meningkat, hal tersebut ditunjukkan oleh hasil penelitian (Shaviklo, dkk, 2012) yang melakukan proses perebusan dan penggorengan pada sampel kerang remis, dimana dengan proses penggorengan kadar air pada kerang remis goreng lebih kecil dari kerang remis segar dan gulai namun kadar protein pada kerang remis yang digoreng lebih banyak daripada kerang remis segar dan gulai.

Tujuan dari pengabdian masyarakat adalah memberdayakan masyarakat untuk mengolah daging rajungan menjadi nugget rajungan, agar dapat menghasilkan nilai jual yang lebih tinggi jika dibandingkan hanya menjual daging rajungan saja sehingga dapat meningkatkan pendapatan warga.

\section{BAHAN DAN METODE}

Jenis pengabdian masyarakat yang digunakan adalah Kuliah Kerja Nyata Pembelajaran Pemberdayaan Masyarakat (KKN-PPM). Lokasi pengabdian terletak di desa Mertasinga 
kecamatan Gunungjati kabupaten Cirebon, dengan durasi waktu kurang lebih 2,5 bulan. Populasi dalam pengabdian ini adalah 30 ibu - ibu warga desa Mertasinga sampel yang bekerja sebagai pengumpul daging rajungan dengan mengambil sampel sebanyak 10 orang.

Teknik sampling yang digunakan adalah simple random sampling. Dengan menggunakan teknik pengumpulan data dilakukan melalui pengamatan, wawancara dan dokumentasi. Data dianalisis dengan menggunakan teknik analisis data deskriptif kualitatif, pada awalnya penulis melakukan penyelidikan mengenai ibu - ibu yang bekerja sebagai pengumpul daging rajungan, kemudian dilakukan proses pengumpulan data dengan mengambil 10 orang sampel ibu - ibu yang bekerja sebagai pengumpul daging rajungan untuk diberikan pembekalan serta praktek pembuatan nugget rajungan, penulis melakukan observasi terhadap setiap proses pembuatan nugget yang mereka lakukan sampai dengan penyajian data dilakukan dalam bentuk tabel data hasil kinerja pembuatan nugget.

Alat yang digunakan dalam pembuatan nugget yaitu: (a) mesin penggiling daging, (b) mixer pengaduk daging dan bumbu, (c) alat pengukus, (d) pisau dan (e) wadah pembuatan nugget. Sedangkan untuk bahan yang digunakan dalam pembuatan nugget pada pengabdian ini adalah bahan - bahan organik sehingga dikatakan nugget sehat, adapun komposisinya terdiri dari : (a) daging rajungan, (b) bawang merah, (c) bawang putih, (d) garam, (e) gula, (f) telur, (g) tepung terigu, ( $\mathrm{h}$ ) susu bubuk, (i) tepung panir, (j) asam kawak dan (k) lada. Langkah yang dilakukan yaitu menguliti rajungan, untuk diambil dagingnya kemudian dicuci sampai bersih. Asam kawak direndam, dan air rendamannya digunakan untuk menghilangkan bau amis pada nugget rajungan. Daging yang telah dilumuri air asam kawak kemudian digiling. Siapkan bumbu untuk diblender yakni bawang merah, bawang putih, garam, gula dan telur. Kemudian campurkan hasil gilingan daging dengan bumbu - bumbu yang telah dihancurkan. Lalu diberikan tepung terigu kemudian kukus. Seperti penelitian yang telah dikukus lumuri daging dengan tepung panir lalu goreng setengah matang.

Jika tidak menggunakan tepung terigu masih ada alternatif lain yang digunakan yakni dengan menggunakan tepung sagu dan tepung maizena. Seperti penelitian yang dilakukan oleh Awaliah, dkk, (2018), mereka menggunakan berbagai jenis tepung yakni tepung sagu, terigu dan maizena sebagai bahan pengisi

\section{HASIL}

Penulis melibatkan 10 orang ibu - ibu yang bekerja sebagai pengumpul rajungan dalam pelatihan pembuatan nugget rajungan dengan rentang usia antara $30-50$ tahun. Materi yang diberikan adalah "Teknik Membuat Nugget Sehat dan Bergizi Tinggi". Berdasarkan pelatihan tersebut didapatkan data peningkatan keterampilan peserta dalam membuat nugget rajungan, sebelum dan setelah pelatihan. Hasil observasi terhadap keterampilan ibu - ibu pengumpul daging rajungan dalam membuat nugget rajungan yang sehat dan bergizi tinggi tanpa zat adiptif sintetis didapatkan nilai rata - rata peserta sebesar $82,075 \%$, dengan nilai terendah $80,25 \%$ dan nilai tertinggi $83,25 \%$.

\section{PEMBAHASAN}

Desa Mertasinga merupakan daerah pesisir, yang mempunyai potensi unggulan berupa hewan laut yakni rajungan. Sebagian besar warga bekerja sebagai nelayan dan hasil tangkapan tersebut kurang dapat dioptimalkan warga karena warga hanya menjual bahan mentahnya saja sehingga nilai jualnya juga rendah. Kurangnya pengetahuan warga dalam mengolah hasil tangkapan menyebabkan keterampilan warga dalam meningkatkan nilai ekonomi menjadi faktor pendukung terhambatnya pertumbuhan ekonomi di desa tersebut. 
Sebagai upaya peningkatan taraf hidup masyarakatnya, perlu dilakukan kegiatan kegiatan yang dapat meningkatkan taraf ekonomi melalui pengelolaan sumber daya alam yang ada. Kegiatan tersebut dapat dilakukan melalui pengolahan daging rajungan menjadi nugget. Agar nugget tersebut mempunyai ciri khas dan kandungan gizi yang baik agar aman dikonsumsi maka dalam pengabdian ini, penulis memberikan pelatihan pembuatan nugget yang sehat dan bergizi tinggi. Proses pembuatannya tentu tidak menggunakan perasa non sintetik atau yang kita kenal dengan MSG (Monosodium Glutamat) dan pengawet makanan sintetis.

Glutamat adalah asam amino dengan peran ganda dalam sel metabolisme dan fisiologi (Blachier, dkk, 2009), mengaktifkan rasa di saluran pencernaan (San Gabriel, dkk, 2009). Maraknya penggunaan pengawet sintetis seperti formalin dan borak yang membahayakan bagi kesehatan sudah tidak diizinkan lagi (Supriatni, dkk, 2017). Berdasarkan literature review tersebut menunjukkan bahwa penggunaan zat adiptif baik sebagai perasa maupun pengawet hendaklah menggunakan bahan alami.

. Hasil uji nugget rajungan terhadap beberapa panelis didapatkan data bahwa panelis lebih menyukai penambahan tepung sagu dengan data sebagai berikut : dari segi warna dan rasa lebih menyukai penambahan tepung sagu dengan konsentrasi $2 \%$, pada aroma penambahan tepung sagu yang disukai dengan konsentrasi 1\%, dan secara tekstur penambahan konsentrasi yang disukai panelis adalah sebesar $3 \%$. Kemudian diuji dengan uji hedonik didapatkan hasil analisis proksimat pada penambahan sagu dengan konsentrasi $2 \%$ didapatkan kadar protein yakni sebesar 31, 29\% dan kadar abu sebesar 5,31\%.

\section{KESIMPULAN DAN SARAN}

Kesimpulan yang dapat ditarik berdasarkan paparan yang telah kita bahas dalam pengabdian ini yaitu : pengolahan daging rajungan agar mempunyai nilai jual yang lebih tinggi dapat diolah menjadi nugget, dengan menjaga kualitas rasa dan gizi agar enak dan aman dikonsumsi maka digunakanlah zat adiptif dari bahan alami. Sedangkan saran yang diberikan dari hasil pengabdian ini adalah agar masyarakat dapat masyarakat diberikan pelatihan mengenai cara pendaftaran hak cipta agar produk tidak diklaim orang lain dan pengemasan serta pemasaran produk agar dapat dipasarkan secara regional, nasional bahkan internasional.

\section{UCAPAN TERIMA KASIH}

Ucapan terimakasih kami berikan kepada Kemenristekdikti yang telah membantu anggaran dana dalam proses hibah pengabdian KKN PPM pada tahun 2019. Tidak lupa kami ucapkan terimakasih kepada pihak LPPM yakni Dr. Badawi, M.Si sebagai ketua LPPM dan Tri Budi Prasetya sebagai sekretaris LPPM yang telah membantu proses penyusunan jurnal pengabdian pada masyarakat ini. Ucapan terimakasih juga diberikan kepada Dr. Murji karena telah menerima artikel ini agar dapat publish di Jurnal Pengabdian UM Tasikmalaya.

\section{DAFTAR PUSTAKA}

Awaliah, R., Yanto, S., \& Sukainah, A. (2018). Analisis Sifat Fisiko Kimia Nugget Rajungan (Portunus Pelagicus) dengan Berbagai Jenis Tepung Sebagai bahan Pengisi. Jurnal Pendidikan Teknologi Pertanian, 3(2), 148-155. 
Blachier, F., Boutry, C., Bos, C., \& Tomé, D. (2009). Metabolism and functions of L-glutamate in the epithelial cells of the small and large intestines. In American Journal of Clinical Nutrition Volume 90.

Diniz, G. S., Barbarino, E., Oiano-Neto, J., Pacheco, S., \& Lourenço, S. O. (2013). Gross chemical profile and calculation of nitrogen-to-protein conversion factors for nine species of fishes from coastal waters of Brazil. Latin American Journal of Aquatic Research, Volume 41 Nomor 2:254-264.

Jacoeb, A. M., \& Lingga, L. A. B. (2012). Karakteristik protein dan asam amino daging rajungan (Portunus pelagicus) akibat pengukusan. Jurnal Pengolahan Hasil Perikanan Indonesia, Volume 15 Nomor 2:156-163.

San Gabriel, A., Nakamura, E., Uneyama, H., \& Torii, K. (2009). Taste, visceral information and exocrine reflexes with glutamate through umami receptors. Journal of Medical Investigation.

Shaviklo, A. R., Thorkelsson, G., \& Arason, S. (2012). Quality changes of fresh and frozen protein solutions extracted from Atlantic Cod (Gadus morhua) trim as affected by salt, cryoprotectants and storage time. Turkish Journal of Fisheries and Aquatic Sciences, Volume 12 Nomor 1:41-51.

Supriatni, D., Said, I., \& Gonggo, S. T. (2017). Pemanfaatan Ekstrak Daun Mahkota Dewa (Phaleria macrocarpa (Scheff.) Boerl) sebagai Pengawet Tomat. Jurnal Akademika Kimia, 5(2), 67-72.

Ubaidillah, A., \& Hersulistyorini, W. (2010). KADAR PROTEIN DAN SIFAT ORGANOLEPTIK NUGGET RAJUNGAN DENGAN SUBSTITUSI IKAN LELE (Clarias gariepinus) (Protein Levels and Organoleptic Crab Nugget with Substitution Catfish (Clarias gariepinus). Jurnal Pangan dan Gizi, Volume 1 Nomor 2:45-54.

Wulandari, E., Suryaningsih, L., Chairunnisa, H., \& Pratama, A. (2016). Karakteristik Mikrobiologi Nugget Ayam Dengan Pasta Tomat Selama Penyimpanan Pada Suhu Refrigerasi (Microbiological Characteristic of Chicken Nugget with The Addition of Tomato Paste During Refrigerated Storage). Jurnal IImu Ternak, Volume 16, Nomor 1:42-45. 


\section{LAMPIRAN}

Tabel 1. Data Hasil Kinerja Peserta Pelatihan Pembuatan Nugget

\begin{tabular}{|c|c|c|c|c|c|c|}
\hline \multirow[b]{2}{*}{ No } & \multirow[b]{2}{*}{ Nama Peserta } & \multicolumn{5}{|c|}{ Keterampilan Pembuatan Nugget } \\
\hline & & $\begin{array}{l}\text { Pengolahan } \\
\text { Daging }\end{array}$ & Pengukusan & Pelumuran & Penggorengan & Rata - Rata \\
\hline 1 & Siyang & 81 & 82 & 84 & 82 & 82,25 \\
\hline 2 & Nur & 80 & 83 & 83 & 83 & 82,25 \\
\hline 3 & Aeni & 76 & 84 & 82 & 85 & 81,75 \\
\hline 4 & Suteni & 77 & 81 & 81 & 82 & 80,25 \\
\hline 5 & Usni & 82 & 80 & 82 & 83 & 81,75 \\
\hline 6 & Tunani & 83 & 82 & 85 & 81 & 82,75 \\
\hline 7 & Suan & 84 & 83 & 77 & 82 & 81,5 \\
\hline 8 & Tusari & 84 & 85 & 76 & 84 & 82,25 \\
\hline 9 & Rumeni & 85 & 84 & 79 & 83 & 82,75 \\
\hline 10 & Asiroh & 85 & 86 & 80 & 82 & 83,25 \\
\hline \multicolumn{2}{|c|}{$\begin{array}{c}\text { Jumlah Total Rata - } \\
\text { Rata }\end{array}$} & 81,7 & 83 & 80,9 & 82,7 & 82,075 \\
\hline
\end{tabular}

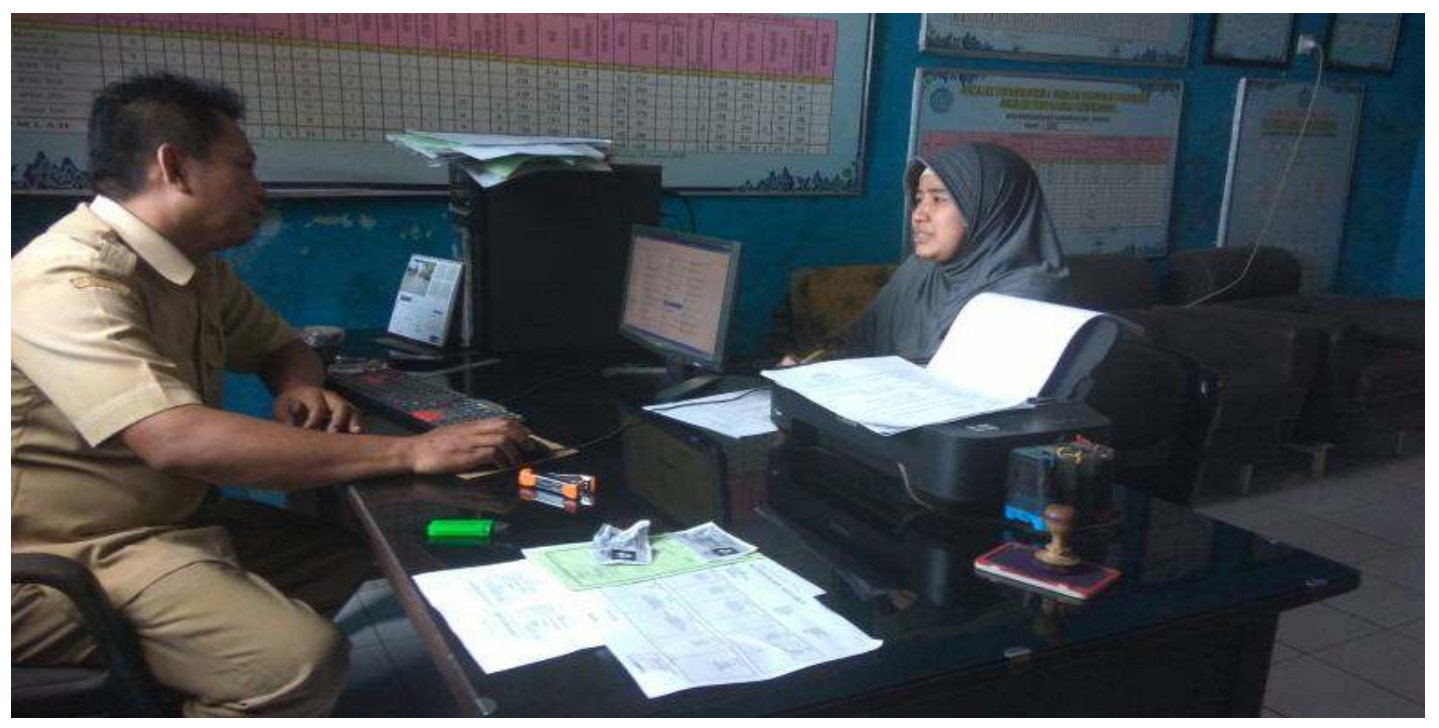

Gambar 1. Survey ke Balai Desa Mertasinga 


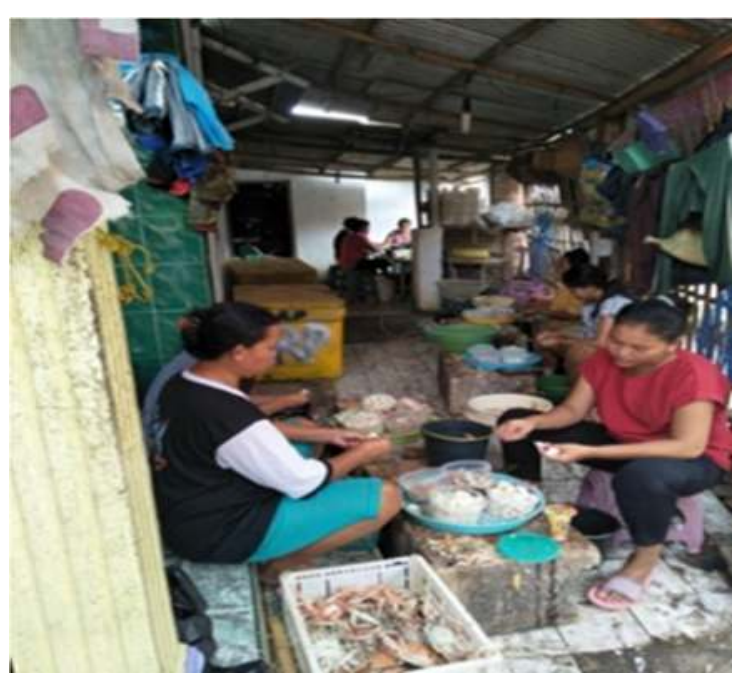

Gambar 2. Proses Pengulitan

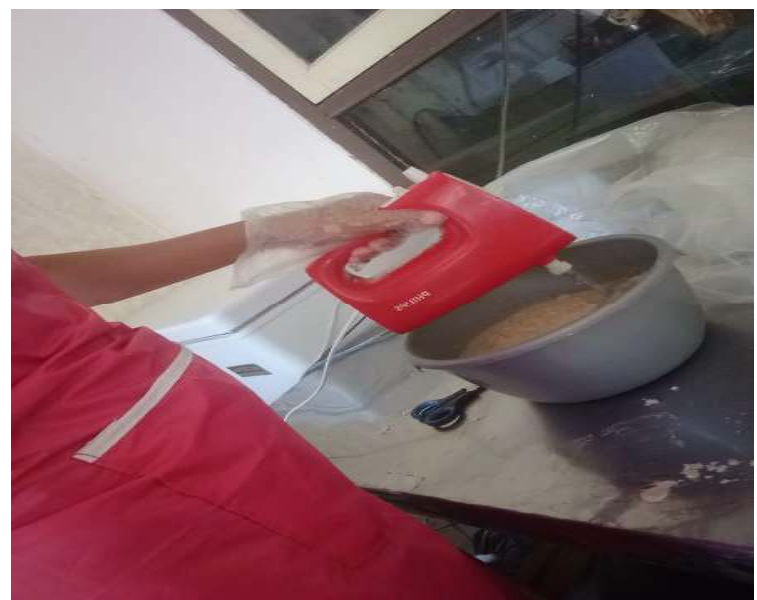

Gambar 4. Proses Pencampuran daging bumbu panir

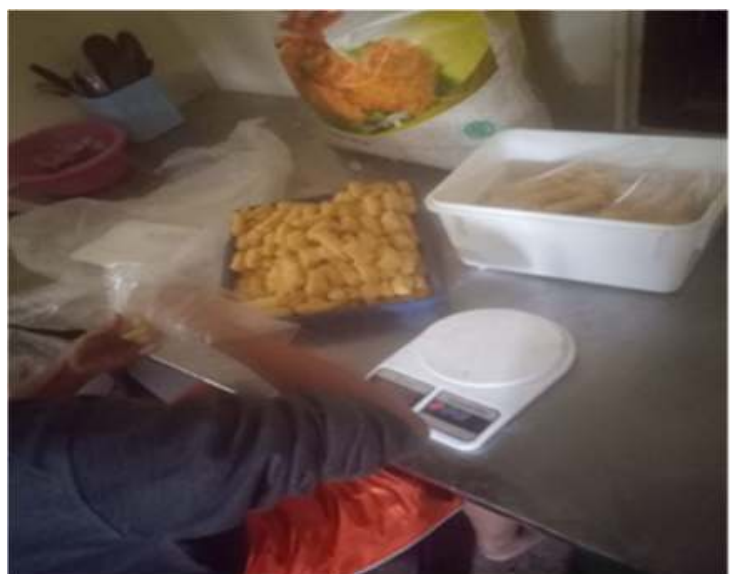

Gambar 6. Pengemasan Nugget

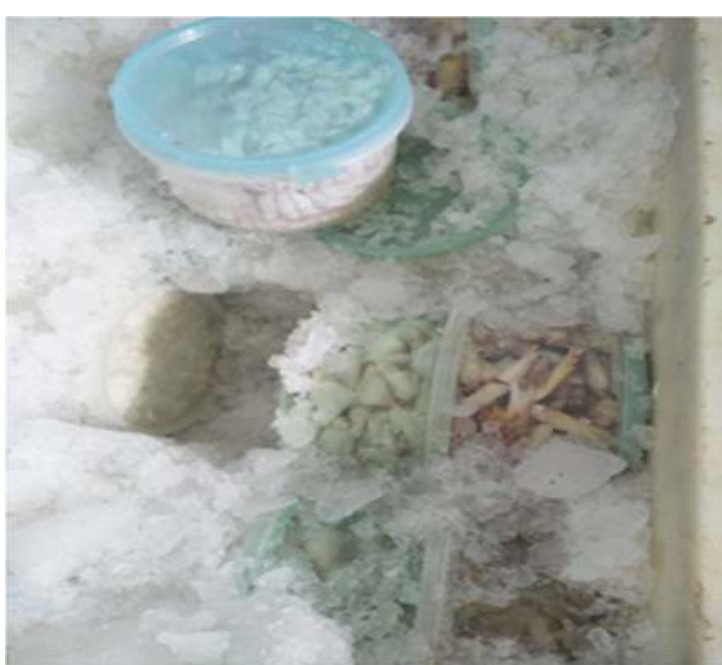

Gambar 3. Daging Rajungan

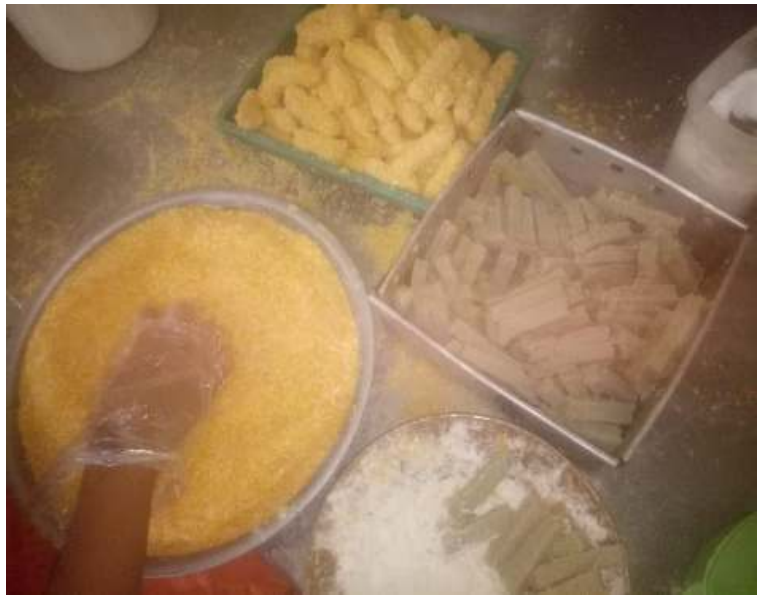

Gambar 5. Proses pelumuran tepung

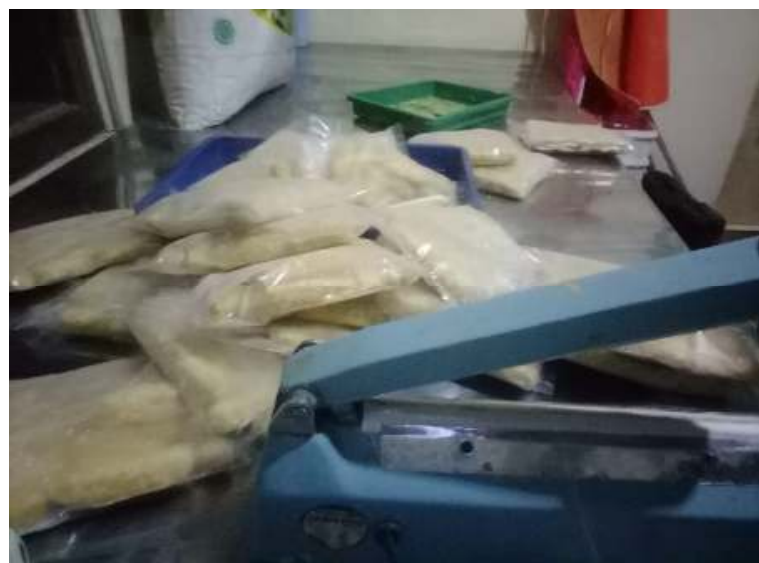

Gambar 7. Laminating Kemasan 